\title{
A STUDY ON VOCABULARY TEACHING STRATEGY FOR STUDENTS WITH HEARING IMPAIRMENT AT SPECIAL EDUCATION SCHOOL (SLB), MAKASSAR, INDONESIA
}

\author{
Reskiana - Haryanto - Sukardi Weda
}

doi: 10.18355/PG.2020.9.2.5

\begin{abstract}
This research aims to find out (1) the vocabulary teaching strategy used by teacher for students with hearing impairment, (2) how to implement the strategy to teaching English vocabulary for students with hearing impairment. This research applied qualitative method. The participants of this research were one English teacher and four students of eight grades SMPLB at SLB Negeri 1 Makassar, Indonesia which were taken through purposive sampling technique. The data of this research were collected by observation, interview, and documentation. The obtained data were analyzed in four major phases namely data collection, data display, data condensation, and drawing conclusion. The result of this research revealed that, (1) there were five strategies used by an English teacher in teaching English vocabulary for students with hearing impairment namely rehearsal, sign language, gesture, writing language and discussion; (2) The teacher implemented the strategies by combining all of those strategies. The teacher showed the material such as explanation and vocabularies to students by writing it on the whiteboard. Next, the teacher explained it to the students by using sign language and gesture, when the teacher gave the students exercise, the students were allowed to discuss the exercise with their friends. All vocabularies the students had learned would be repeated until they were familiar and memorized the those vocabularies.
\end{abstract}

\section{Key words}

vocabulary, teaching strategy, students with hearing impairment

\section{Introduction}

Education is one of the most essential parts of one's life. All people from all over the world regardless of their gender, faith, social status, race even intellectual background. By gaining a decent and good quality of education, one's dignity will be lifted up and meet one's expectation to adapt to his or her community. Furthermore, one's knowledge and skill will be indeed useful to be applied in a community. Moreover, in referring to that issues, we must recognize the meaning of an inclusive education in which these disabled students study.

Wardani (2009) argues that person with special needs or disable has the same rights to get the equal education. The Government of the Republic of Indonesia supports the statement as revealed in UUD 1945 point 31 and described further in UU No. 21989 in point 8 article 8, as follows: 1.Citizen with physical and or mental disorders have the right to receive an exceptional education.' 2. Citizen who have an exceptional intelligence have the right to 
receive special attention.

Moreover, in relation to the above explanation, we must recognize the meaning of an inclusive education in which these disable students study. All categories of disable students have the same right as the normal students to receive the good quality of education even the students with hearing impairment.

In term of globalization, it is necessary to learn foreign languages and one thing that may not ignored in teaching and learning English as a foreign language both normal and disable students is teaching vocabulary. Chamont (2005) mentions that the strategies to teach disable students are different with normal student. Studies about teaching strategy for disable students have been conducted by some researchers. One of them is Miyosi (2010) who observed the effectiveness of strategies in English language teaching of down syndrome students and the result of her research was the down syndrome students have disability in absorbing some information, the teacher did not use only one method but also combined with some appropriate methods, the researcher have some problems while teaching English, and some possible solutions in order to solve the problems. The other study is from Fatma (2014) which showed that visual materials are more effective than the sign language which does not include any visual materials in teaching vocabulary to deaf learners of EFL. Therefore, this study focuses on exploring the strategies used by the teacher to teach English vocabulary for students with hearing impairment at SMPLB at SLB Negeri 1 Makassar, South Sulawesi Indonesia.

\section{Literature Review}

\section{Hearing Impairment}

According to Seng (2001), deaf or hearing impairment is defined as a genetic term indicating a hearing disability that may range from mild to profound, including the subsets of deaf and hard of hearing. So, it can be define that a hearing impairment can make learning very difficult for the students. Students who are born deaf or experience a significant hearing loss in the first several years of life usually do not develop normal speech and language.

Hearing ability of someone could not be known at the first birth. But if there is cognitive defect, it will grow up continue. Bandie (2006) say that students that did not have problem with their hearing abilities will get good result or accurate information that comes into their brain according to what they have studied. Hearing impairment is the consequence of a functional loss of hearing; actually students with hearing impairment also have speaking disabilities. It will be one of the teacher's jobs to get their students come into the lesson. For example in teaching reading, teachers must explain the material and give the instruction by using signal language. Although the material is very simple, teachers have a big duty of the student's development, even their ability in studying English and also their attitude.

\section{Vocabulary}


Vocabulary is the prime foundation for every language learning as well as the English language. It is hard for students in mastery English language without knowing the meaning of the words both written and oral. (Ur, 2009) states "Vocabulary can be defined, roughly, as the word we teach in the foreign language. However a new item in a vocabulary may be more than a single word". While, Gardener in Adger (2002) states that "vocabulary is not only confined to the meaning of words but also includes how vocabulary in a language is structured" It means that it relates to how people use and store words, how they learn words and the relationship between words, phrases, categories of words and phrases. Its mean that in learning vocabulary we have to know the meaning of the words itself and also understand and can use it in sentence context.

Hiebert and Kamil (2005) categorize vocabulary into two forms namely productive vocabulary and receptive vocabulary. Productive vocabulary is the set of words that an individual uses when writing or speaking. Meanwhile, receptive vocabulary is the set of words that can be used when listening or reading. This defines vocabulary type based on the usage, related to each English skill. Productive vocabulary means that the students, which those are familiar, produce the words well known and used frequently in writing a sentence or essay and in speaking.

\section{Teaching Strategy to Teach Disable Students}

Teaching strategy is a contract between a student and a teacher. This implies that teacher and students have an agreement and some distinct obligations to each other. Larsen (2000) states that "As a teacher of language, you have thoughts about your subject matter, what language is, what culture is, and about your students, who they are as learners, and what you can do to help your students learn. It is very important for you to become aware of the thoughts that guide your actions in the classroom"

In addition, Brown (2000) states strategies are specific methods of approach a problem or task, modes operation for achieving a particular end, planned designs for controlling and manipulating certain information. Teaching strategies refer to the structure, system, methods, techniques, procedures and processes that a teacher uses during instruction. These are strategies the teacher employs to assist student learning. Chamont (2005) say that the strategies to teach disable students is different with normal students, some of strategies are: Total Physical Response (TPR), Gesture, sign language and Writing Language Approach.

\section{Method}

The research method used in this study was qualitative method, because the purpose of this research focuses on how the teacher teaches English vocabulary to students with hearing impairment in Special Education School and what strategy that the teacher use. This study was carried out at SLB Negeri 1 Makassar at eight grades. This study used purposive sampling in defining the sample of the research. The participants are four students of grade VIII SMPLB of SLB Negeri 1 Makassar and one English teacher. The student's ages are about 12 until 14 years old. They 
are categorized in groups of students who have hearing impairment. Based on researchers's pre-observation, SLB Negeri 1 Makassar have applied SLB 2013 curriculum, in which all of categories learn English as one of the subject. The data of this research were collected by observation, interview and documentation then analyzed through interactive model of Miles \& Huberman (2014).

\section{Findings}

Vocabulary teaching strategies used by teacher for students with hearing impairment at SLB Negeri 1 Makassar

\section{Rehearsal}

Rehearsal is the literal repetition of the exact words you want to remember. It can be oral, visual or written. It was the first types of strategy the teacher mentioned when the researcher did interview. The teacher used this strategy to make her students understand the lesson and memorize vocabulary quickly. As stated by teacher in interview conducted on $3^{\text {rd }}$ February 2020 as follow:

"jadi starateginya mengulang ulang terus, sampai mereka faham dan hafal" (so the strategy is repeating until they memorize it and understand.)

(Source:Interview)

"Mereka bisa cepat hafal, jadi setiap masuk lagi belajar, dia bisa tau walaupun Cuma sedikit-sedikit tapi karena kita sering ulangulang, maka itu akan menjadi memorinya sendiri, seperti itu”.

(the advantage is they can learn quickly, so they can understand step by step in every meetings)

(Source: Interview)

In line with the teacher activities during teaching, the teacher began her class with repeating the previous material. For example, the teacher asked the students wrote vocabulary that the students had learned on last week. The teacher made sure that her students have understood and still remember the vocabulary.

\section{Sign language}

Sign language is generally used for people who have hearing impairment in communication. Even though in teaching and learning process, sign language was a strategy used by English teacher to teach students with hearing impairment. The teacher used this strategy to communicate with students and the way to explain the material to the students. As stated by teacher on interview as follow

Teacher :"kalau strategi lain yang ini, secara lansung. Apa lagi namanya itu? Kata kan, kita bahasakan dengan isyarat, nah dia lebih cepat. Strategi apa lagi namanya itu, saya lupa.

(hmmmm. The other strategy, that's directly. What strategy is it? For examples when we tell something by 


\section{using sign. That is more faster. I forget the name.) \\ Researcher: Sign language? \\ Teacher : ohhh iya itu.}

(oh, yes. That is sign language)

(Source: Interview)

The statement above shows that the teacher used sign language as direct strategy in teaching vocabulary. The students understood more quickly, because they had accustomed to doing that. For example, when the teacher said "Sugar" and also used sign language in the same time, the students understood that what the teacher means by sugar was gula. Below is a student and teacher conversation in the class during the lesson, as follow:

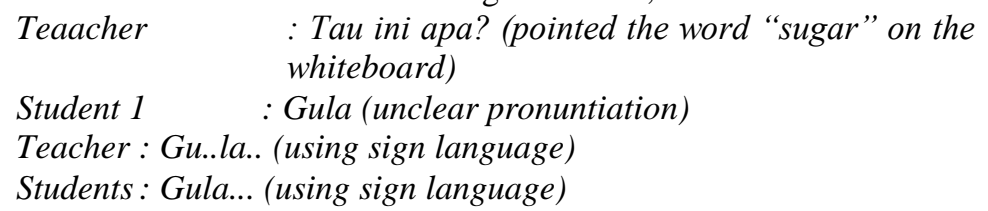

(Source: Observation transript)

Based on transcript above, we can see that before the teacher used sign language, only students A understood the meaning of word "sugar", but when the teacher used sign language, all students knew that "sugar" is gula. It was the teacher said on interview that by using sign language the students were able to knew the vocabulary quickly

\section{Gesture}

Gesture is a strategy used by teacher in teaching vocabulary for students who have hearing impairment. This strategy helped the students know what the teacher said by looking the teacher body movement. As the teacher stated on interview and the teacher and students conversation when teacher explained something to the students as follows:

"kadang juga toh selain menggunakan sign language saya jga menggunakan gesture, biasanya kalo digerakkan itu siswa lebih cepat faham. Misalnya klo mau bilang sit down sya juga ikut duduk, yahhh begitu"

(sometimes, besides using sign language, I also using gesture. The students will understand quickly. For example when I said sit down I will sit down in the same time.)

(Source: Interview)

Teacher : tau short massage?

Students : (shaking head and murmuring)

Teacher : yang ini (typing gestures)

Students $1 \quad$ :WA?

Teacher : yaaaa. yang itu, tau?

Students : (nodding and murmuring)

(Source: Observation, Meeting 2)

This conversation occurred when the teacher explained the types of short massage to the students. All students understood when the teacher did typing gesture; the teacher moved her hand as if typing on cell phone. It means that gesture strategy has good effect used in teaching vocabulary for students who 
have hearing impairment.

\section{Written Language}

Written language is one of ways used by teacher to teach vocabulary for students with hearing impairment. Different from normal students, students with hearing impairment cannot communicate with normal language. During observation, when the teacher explained something to students, she always wrote the explanation on the whiteboard then red it again to students. Almost the teacher explanation she wrote on the whiteboard before. As the teacher statement on interview as follow:

Interviewee :Iya, karena mereka memang harus begitu, harus diulang - ulang. Jadi misalnya saya menjelaskan saya juga tulis penjelasannya dipapan tulis. Itu supaya mereka lebih cepat mengerti.

(yes, because it has to repetly. So if I explained something I have to write it before on white board, so that they will understan quickly.)

Researcher : Kalau cara yang ibu lakukan itu namanya strategi apa?

(What type of strategy is that?)

Interviewee : apa yahh? kalau menurut saya itu mungkin bisa disebut Writen strategy, karena selain menjelaskan saya juga harus menuliskannya kepapan tulis.

(what is that?, in my mind, it can be called written strategy. Because besides explaining I have to write it also in whiteboard.)

(Source: Interview)

The teacher statement above about written stagey, explain that the teacher not only wrote the material on whiteboard but also the explanation or the instruction, so that the students would understand quickly because they could read the writing on the board while seeing the teacher explanation. The other reason was the teacher would explain for many time.

\section{Discussion}

Discussion strategy was one of strategies used by the teacher to teach students who have hearing impairment. Like a normal students, disable students are also have different abilities in learning. Therefore, the teacher used discussion strategy to make the students easier when did some exercises. The transcript below is the teacher answers when the researcher asked her about discussion strategy on interview, as follows:

Researcher :yang saya lihat juga ibu beberapa kali meminta mereka berdiskusi pada saat mengerjakan latihan, apa itu juga merupakan strategi mengajar ibu?

(you also asked them discussed while did excercise. Is that your strategy?)

Interviewee:Yaa, yang itu strategi juga. Itukan mengajarkan mereka bekerja sama. Kan ada yang pintar ada juga yang kemampuannya kurang. Makanya saya bagi 
supaya lebih mudah mengerjakan soal. Bisa lebih cepat, kalo sendiri-sendiri itu lama. Kadang juga kalo temannya yang jelaskan toh, mereka lebih cepat faham, jadi lebih mudah.

(sure, it was also my strategy. It teaches the students how to work together. As we know, there are some students have high competence and also low competence. Therefore, sometimes I ask the students to discuss. They can do the task faster with discussion than to do it by them self. They will understand more quickly, if it explained by their friend.)

(Source: Interview)

How to implement the strategies used by English teacher to teach vocabulary for students with hearing impairment at SLB Negeri 1 Makassar

\section{Rehearsal}

The teacher implemented this strategy in the class by several ways. The first way was the teacher began her class with asked the students to write vocabularies that the students had learned on last meeting. The teacher made a blank list of vocabularies on whiteboard with instruction that the students had to fill it.

This repeating lesson was very useful, to make sure that the students still remember the vocabulary. The teacher also used some of the same vocabularies in several meetings. Therefore, the students would memorize the vocabulary because they were familiar with the words. The second way was the teacher pronounced a word repeatedly and the students followed it. It can be seen in appendix 4 meeting 1 as follow:

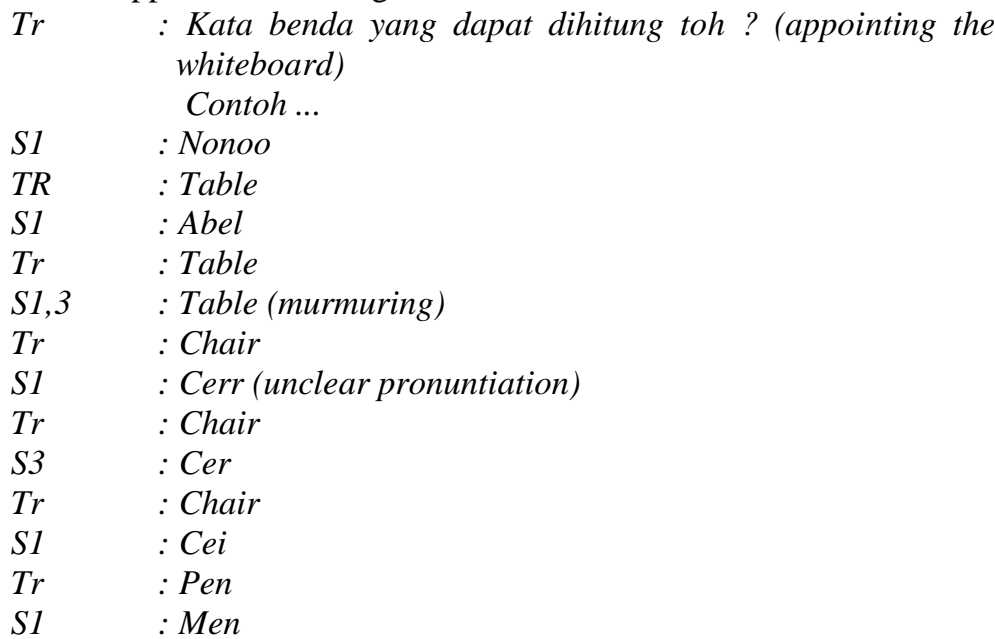
(Source: Observation's transcript)

Sign Language 
There were two types of sign language the teacher and the students used in class during observation. They were sign language based-word and sign language based-alphabet. Sign language based-word would be translated by one word per sign.

The teacher explained the meaning of words "don't forget" to students, the teacher did two sign, and they were waving hands and rubbing three fingers on her forehead, as the pictures showed below:

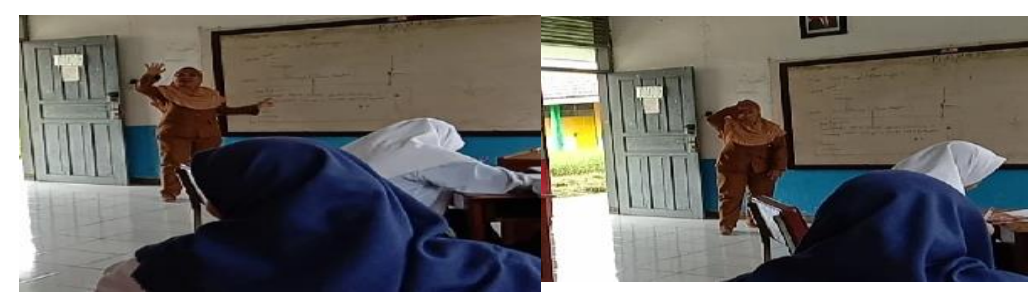

Figure 1.Teacher Waving Hands and Rubbing Three Fingers on Her Forehead (Sign Language)

Two pictures above showed how the teacher implements sign language based-word in teaching English vocabulary. When the teacher would tell the meaning of English word, she used this strategy.

Differently, sign language based-alphabet must be translated by one sign for one alphabet. They sorted the signs by following the alphabetical arrangement in one word. For example: when the teacher said "program", the teacher spelled the word by using sign. As the teacher and the students conversation below during the lesson as follow:

$\begin{array}{ll}T r & \text { : berdiskusi tentang (with sign and gesture) } \\ & \text { Program } \\ \text { S1 } & \text { : proam } \\ T r & \text { : apa yah.. } \\ & \text { : hmmmm apa yah ? tau program? } \\ & \text { Apa itu bahasa lainnya program? } \\ & \text { p-r-o-g-r-a-m } \\ \text { S1 } & \text { : Proam } \\ T r & \text { : program } \\ \text { S1 } & \text { : ohhhh. (using sign language) }\end{array}$

(Source: Observation's transcript)

\section{Gesture}

There were many gestures the teacher did while explaining the lesson to the students in class. The teacher's always employed the same gestures to tell the same word or instruction, so that the students would become accustomed to it. Furthermore, when the teacher did the same gesture the students would understand what the teacher mean even if the teacher occasionally leaved out 
the oral instruction. The kinds of gestures the teacher always used such us give a thumb up to students which means their answer were correct, shake one's head which means the students answer was wrong, knocked the white board with the marker which means asking for attention, shrugging which means asking the reason, nodding which means yes, raising both hands which means start to pray.

\section{Written Language}

The teacher used Written Language in every meeting during observation. The way the teacher implemented this Written Language was by wrote the explanation or instruction of the lesson on whiteboard. The explanation must be clearly enough to understand by students, so that the teacher wrote it by English and Indonesian.

\section{Discussion}

There were two ways the teacher implemented this method during observation. The first was, the teacher are divided the students into two groups, two students per group. The teacher let the students discussed during doing exercise. It can be seen from observation's transcript below:

$$
\begin{gathered}
\text { Tr : Ohhh hp } \text { ? (with gesture) } \\
\text { : kerja kelompok ya (using sign language) } \\
\text { : Ayoo kelompok, tulis dulu. (with sign language) } \\
\quad \text { : hey, S1 Dengan S4. S2 disini sma 3(with gesture) } \\
\text { S1 } \quad \text { : Sini (using sign language) } \\
\text { : Kamu disini } \\
: \text { Isi tabel ini } \\
\text { : catat dlu baru disisi (with gesture and sign } \\
\text { language) }
\end{gathered}
$$

(Source: Observation transcript)

The second way was discussion led by students. The teacher asked the student who had finished the exercise first to explain the instruction to the others students. So that they could discussed but still watched over by the teacher. It can be seen on observation transcript below:

$$
\begin{aligned}
& \text { St1 : bu sudah (giving her book to the teacher) } \\
& \text { Tr } \quad \text { :yang lain sudah? (with sign language) } \\
& \text { Salah, punyanya S1 sudah benar (with sign language) } \\
& \text { Jelaskan dlu sama temanmu (with sign language) }
\end{aligned}
$$

(Source: meeting 2)

The student who had already understood and finished the exercise would tell the students who had not understand, and doing discussed. Sometimes the students would understand more quickly if explained by their friend, but still watched over by teacher.

\section{Discussion}


The findings of this research shows that there are five strategies that the teacher use to teachs disable students specially for students with hearing impairments in SLB Negeri 1 Makassar. The strategies are; Rehearsal, Singn Language, Gesture, Writing Language and Discussion. These findings supports by several studies (Fatma, 2014; Nadhiroh, 2017) who investigated about learning and teaching vocabulary for the disable students. They claim that Gesture, Sign Language and Written Language are appropriate strategies used for students with disability. In addition, (Mutiatun, 2011) found several strategy that used for teaching students with disability, and one of strategy used in these study was discussing strategy. The using of Rehearsal strategy is in coincident with article by (Neer, 2015) who states that "Rehearsal influences the attention and storing of information in memory, but it does not help construct meaning or relate the information to what you already know. Thus, rote repetition is most useful for exact information, such as the alphabet, spelling, sight words, times table, etc.“

\section{Conclusions and Suggestion}

From the result of this study, there are two conclusions obtained. First, the researcher found some strategies used by an English teacher of SLB Negeri 1 Makassar in teaching vocabulary for students with hearing impairment (disabled students), they were: Rehearsal, sign language, gesture, written language and discussion strategy. Second, the teacher implemented the strategies by combining all of them. The teacher showed the material such as explanation and vocabularies to students by wrote it on the whiteboard. Next, explained to the students by using sign language also gesture, when the teacher gave the students exercise the students were allowed to discuss with their fried. All vocabularies the students had learned would be repeated until they were familiar and memorize he vocabulary.

Finally the researcher suggests those who wish to conduct the similar study to do the following efforts: to observe more deeply the strategy used for other skills in English for students with hearing impairment, to dig more information concerning students with disability and students with hearing impairment; to observe teachers to implement the other strategy for disable students and the other categories of them. To find out more information concerning with the most suitable strategy using in the classroom students with hearing impairment, to collect more data and analyze them comprehensively in order to gain a more valid and meaningful study. These efforts are aimed to help these students to have English competence since they have equal right with the other regular students to acquire it. As the result, by implementing such teaching strategy, observing them during their learning activity, evaluating them, the goal of learning process is obtained.

\section{Bibliographic references}

ADGER, C.T. 2002. What Teachers Need to Know about Language, London: Merril Publising Company.

BANDIE, D. 2006. Pembelajaran Anak Berkebutuhan Khusus, Bandung:

PT. Refika Aditama. 
BROWN, H. DOUGLAS. 2000. Principle of Language and Teaching (fourth edition). New York: Longman

CHAMONT, A. 2005. Language Learning Strategy Instruction special abilities:Current Issues and Research. Annu al Review of Applied Linguistics, vol. 25, pp. 112-130.

FATMA. 2014. The Effectiveness of Visual Materials in Teaching Vocabulary to Deaf Students of EFL. Haccettepe Univarsity.

HIEBERT, ELFRIEDA, H. - KAMIL, MICHAEL L. 2005. Teaching and learning vocabulary: Bringing Research to Practice. New York: Lawrence Erlbaum associates, Inc.

LARSEN, D. 2000. Techniques and Principles in Languages Teaching. Wachington, D. C: Oxford University Press

MIYOSI, E. 2009. Teacher's Effective Strategies In English Language Teaching of Down Syndrome Students of SMPLB Batang In Academic year 2009/2010. Semarang: IKIP PGRI.

MUTIATUN, S. 2011. Technique of Teaching English as A Second Language for Students With Different Ability at State Institute for Islamic Studies Sunan Ampel Surabaya. State Institute for Islamic Studies of Sunan Ampel, Surabaya.

SENG, T. O. 2001. Educational Psychology: A Practitioner-Researcher Approach. Singapore: Thomson Asia Pte Ltd,

UR, P. 2009. A Course in language Teaching: Practice and Theory. United Kingdom: Cambridge University Press.

WARDANI. 2009. Pengantar Pendidikan Luar Biasa. Jakarta: Universitas Terbuka.

Reskiana, S.Pd., M.Pd.

English Department, Graduate Program

State University of Makassar

Makassar

Indonesia

reskiana.reskiana04@gmail.com

Prof. Dr. Haryanto

English Department

State University of Makassar Indonesia

Jl. Pettarani, Makassar

Indonesia

sukardi.wea@unm.ac.id

assoc. prof. Dr. Sukardi Weda

English Department

State University of Makassar Indonesia

Jl. Pettarani, Makassar

Indonesia

sukardi.wea@unm.ac.id 